\title{
Design and development of polymerase chain reaction thermal cycler using proportional-integral temperature controller
}

\author{
Kim Soon Chong a, Nawoor Anusha Devi ${ }^{b}$, Kok Beng Gan a, , Sue-Mian Then b \\ a Centre for Advanced Electronics \& Communication Engineering (PAKET), Faculty of Engineering \& Built Environment, Universiti Kebangsaan \\ Malaysia, 43600, UKM Bangi, Malaysia \\ b School of Biomedical Science Faculty of Medicine \& Health Sciences, University of Nottingham Malaysia Campus, 43500, Semenyih, Selangor, \\ Malaysia \\ *Corresponding author: gankokbeng@ukm.edu.my
}

\section{Article history}

Submitted 1 October 2017 Revised 2

February 2018

Accepted 15 April 2018

Published Online 4 June 2018

\section{Graphical abstract}

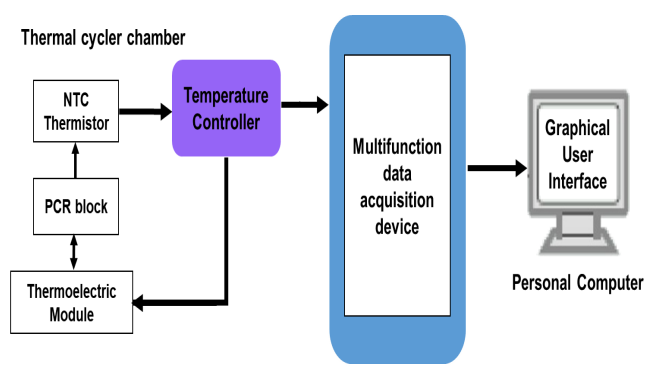

\begin{abstract}
A thermal cycler is used to amplify segments of DNA using the polymerase chain reaction $(\mathrm{PCR})$. It is an instrument that requires precise temperature control and rapid temperature changes for certain experimental protocols. However, the commercial thermal cyclers are still bulky, expensive and limited for laboratory use only. As such it is difficult for on-site molecular screening and diagnostics. In this work, a portable and low cost thermal cycler was designed and developed. The thermal cycler block was designed to fit six microcentrifuge tubes. A Proportional-Integral temperature controller was used to control the thermal cycler block temperature. The results showed that the maximum temperature ramp rate of the developed thermal cycler was $5.5^{\circ} \mathrm{C} / \mathrm{s}$. The proportional gain $\left(\mathrm{K}_{\mathrm{p}}\right)$ and integral gain $\left(\mathrm{K}_{\mathrm{i}}\right)$ of the $\mathrm{PI}$ controller were $15 \mathrm{~A} / \mathrm{V}$ and $1.8 \mathrm{~A} / \mathrm{Vs}$ respectively. Finally, the developed thermal cycler successfully amplified six DNA samples at the expected molecular weight of 150 base pair. It has been validated using the Eppendorf Mastercycler nexus gradient system and gel electrophoresis analysis.
\end{abstract}

Keywords: Polymerase chain reaction, proportional-integral temperature controller, thermal cycler

\section{INTRODUCTION}

Polymerase chain reaction (PCR) has become an important tool for DNA replication in biomedical research since 1985 (R. K. Saiki et. al., 1985; K. B. Mullis and F. A. Faloona, 1987). PCR is an in vitro technique which allows the amplification of a specific deoxyribonucleic acid (DNA) region that lies between two regions of known DNA sequence (G. L. Shipley, 2008). PCR has been elaborated in many ways since its introduction and is now commonly used for a wide variety of applications including genotyping, cloning, mutation detection, sequencing, microarrays, forensics, and paternity testing (K. B. Mullis and F. A. Faloona, 1987; G. L. Shipley, 2008; K. B. Mullis, 1990). PCR is a three-step reaction. The PCR reaction solution contains the DNA template, DNA polymerase, primers, deoxynucleoside triphosphates (dNTPs), and buffer (T. M. Powledge, 2004). In the first step of PCR, the sample is heated up to $94-98^{\circ} \mathrm{C}$, which denatures the DNA and splits it into two single-stranded DNA molecules. In the second step, the temperature is decreased to approximately $50-65^{\circ} \mathrm{C}$, allowing the primers to bind, or anneal, to specific sequences of DNA at each end of the target sequence (DNA template). In the third step, the temperature is increased to $72^{\circ} \mathrm{C}$, allowing the DNA polymerase to extend the primers by the addition of dNTPs to create a new strand of DNA, thus doubling the quantity of DNA in the reaction solution. This sequence of denaturation, annealing, and extension is repeated for many cycles, resulting in the exponential amplification of the initial DNA template. The process of repetition is know as PCR. As the number of PCR cycles increase, the DNA polymerase loses its activity, the dNTPs and primers are consumed and the PCR reaction finally reaches a plateau phase (G. L. Shipley. 2008; T. M. Powledge. 2004; K. B. Mullis et. al., 1986).

Thermal cycler, also known as PCR machine or thermocycler, is a laboratory instrument used to amplify segments of DNA via PCR. It is also used in laboratories to facilitate other temperature-sensitive reactions, including, but not limited to, restriction enzyme digestion or rapid diagnostics (D. P. Clark and N. Pazdernik. 2013). The PCR machine provides a thermally controlled environment for the PCR reaction solutions. It employs precise temperature control and rapid temperature changes to conduct PCR. The thermocycler contains a metal heating block with holes or depressions in it that receive microcentrifuge tubes. Most of commercial thermal cycler available in the market use aluminum or silver material to build the heating block (PCR block) (E. T. Lagally et. al., 2000). For an effective DNA amplification, the temperature of the reaction solution in the microcentrifuge tube must be changed quickly, repeatedly and accurately between the three stages, which are characterized by high ramping temperature and short temperature holds $(\mathrm{Q}$. H. Wang et. al., 2003). The temperature control of the PCR block is mostly performed with proportional-integral-derivative (PID) temperature controller due its simple algorithm, robustness and stability (D. J. Sadler et. al., 2003; J. Chiou et. al., 2001). The purpose of the PID temperature controller is getting the PCR block to the correct temperature, and then maintaining it at that temperature. The performance of the PID 
temperature controller depends on the values of proportional, integral, and derivative gains of the PID temperature controller. Setting an unsuitable gain value in the PID temperature controller will cause the PCR block temperature overshooting or undershooting of the desire PCR block temperature (A. O'Dwyer. 2009). The temperature overshooting causes time delays, and overheating. This could result in damage to the DNA sample. Conversely, the temperature undershooting can lead to incomplete reactions, as the DNA sample is not at the optimum temperature for long enough (Y. H. Kim et al., 2008).

Recently, the demand for on point care system for molecular diagnostics has increased (S. T. John A. and C. P. Price. 2014) Sending the DNA samples to a central laboratory facility for testing has disadvantages, particularly the time period between sampling and diagnosis, and in some circumstances, it would be highly desirable to perform testing immediately at the point of sampling in hospitals. Access to decentralized molecular diagnostic testing can enable faster diagnostics, treatments, and subsequent control of infectious diseases and adverse drug reactions (ADRs). Therefore, commercial portable thermal cyclers have been developed to perform on-site quantitative and qualitative DNA analysis such as Mini8 Plus real-time PCR system, Mic qPCR system, MyGo mini real-time PCR system and Chai real-time PCR system. However, most of commercial PCR instruments are still bulky and expensive. The lack of affordable and portable thermal cycler tends to limit ease of diagnosis especially for developing countries and rural areas. The availability of a low cost portable thermal cycler would significanlty improve healthcare in low resource settings and act as a bedside screening device.

In this project, we developed a portable PCR system with high temperature ramping rate and low cost. The thermocycler consists of heating chamber, controller and graphical user interface (GUI). The system was assembled using commercial off-the-shelf items to reduce the prototyping cost. Proportional-Integral (PI) temperature controller was proposed in this work to control the PCR block temperature. It was applied in the developed thermal cycler due to its simplicity and noise immunity compared to PID temperature controller. The derivative-term of PID temperature controller could cause a fast change in the PCR block temperature and destabilize the block temperature due to noise response (Wavelength Electronic Inc., 2005) The effect of proportional gain value against temperature ramp rate of the developed thermal cycler was evaluated in this work. The six DNA samples were amplified under the optimum PI temperature controller parameter setting. The amplified DNA samples were verified using agarose gel electrophoresis analysis and compared with commercial thermal cycler (Eppendorf Mastercycler Nexus Gradient). The cost of development and temperature ramp rate of the developed thermal cycler was compared with the existing, commercialized portable PCR machines in the market.

\section{MATERIALS AND METHODS}

\section{Polymerase Chain Reaction Protocol}

Standard PCR reactions were carried out with a pair of primers targetting a region of 150 base pair (bp) long. A standard, optimised $25 \mu \mathrm{L}$ reaction contained $1 \mathrm{x}$ HotStar Taq Master Mix (Qiagen, Germany)., $0.2 \mathrm{uM}$ of both reverse and forward primers, followed by 3.5 $\mu \mathrm{L}$ RNAase-free water (Qiagen, Germany) and 150ng of DNA template. The PCR was performed using the developed prototype and benchmarked against the Eppendorf Mastercycler Nexus Gradient machine. Amplification started with an initial denaturation of 910 seconds at $95^{\circ} \mathrm{C}$, followed by 35 cycles of 70 seconds at $94^{\circ} \mathrm{C}$ for denaturation, 70 seconds at $50^{\circ} \mathrm{C}$ for annealing, 70 seconds at $72^{\circ} \mathrm{C}$ for extension and 600 seconds at $72^{\circ} \mathrm{C}$ for the final extension. Table 1 shows the temperature and dwell time for each DNA amplification stages. The PCR products were analysed on a $1.0 \%$ agarose gel made with $1 \times$ Tris Acetate-EDTA (TBE) buffer, agarose powder and SYBR safe stain (Invitrogen, California). 10x Blue Juice gel loading buffer (Thermo Fisher Scientific, USA) was added to samples to be analysed and the 100bp ladder (Thermo Fisher Scientific, USA) which was used as reference to estimate the PCR product size. Gel electrophoresis was (Bio-Rad Laboratories Inc., California) run at $80 \mathrm{~V}$ for 60 minutes.

Table 1 PCR temperature cycling profile for five stages. Each stages has specific heating temperature and period.

\begin{tabular}{ccc}
\hline Stages & Temperature $\left({ }^{\circ} \mathbf{C}\right)$ & Period (minutes) \\
\hline Pre-heat & 95 & 15 \\
Denaturation & 94 & 1 \\
Annealing & 50 & 1 \\
Extension & 72 & 1 \\
Final Extension & 72 & 10
\end{tabular}

\section{Thermal cycler system design}

Fig. 1 shows the block diagram of the developed thermal cycler. The thermal cycler consist of a heating chamber, control chamber, power management and a personal computer. A PCR block was designed to fit six standardized $0.1 \mu \mathrm{L}$ microcentrifuge tubes. It was designed by using Autodesk Fusion 360 software. The dimension of the PCR block was equal to $30.0 \times 20.6 \times 6.6 \mathrm{~mm}$. It was built by aluminium alloy, 6082 material. A thermal electric module (APHC12708-S) was used to heat up and cool down the PCR block. The cooling side and hot side of thermal electric module were PCR block and a liquid cooler (Seidon 120V Plus) respectively. A PI temperature controller (PTC10K-CH) was used to control the thermal electric module. The temperature of PCR block was measured by a negative temperature coefficient (NTC) thermistor (TCS651). It acts as a temperature feedback system to the PI temperature controller. A data acquisition (DAQ) device (NI USB-6009) with a sampling frequency equal to $1000 \mathrm{~Hz}$ and 16-bit resolution was used to control the PI temperature controller and record the PCR block temperature. A customized graphical user interface (GUI) was developed in the personal computer to display the PCR block temperature and saved temperature data in a text file for further processing. An alternating current (AC) adapter (LS150-15) was used to supply power to the developed thermocycler.

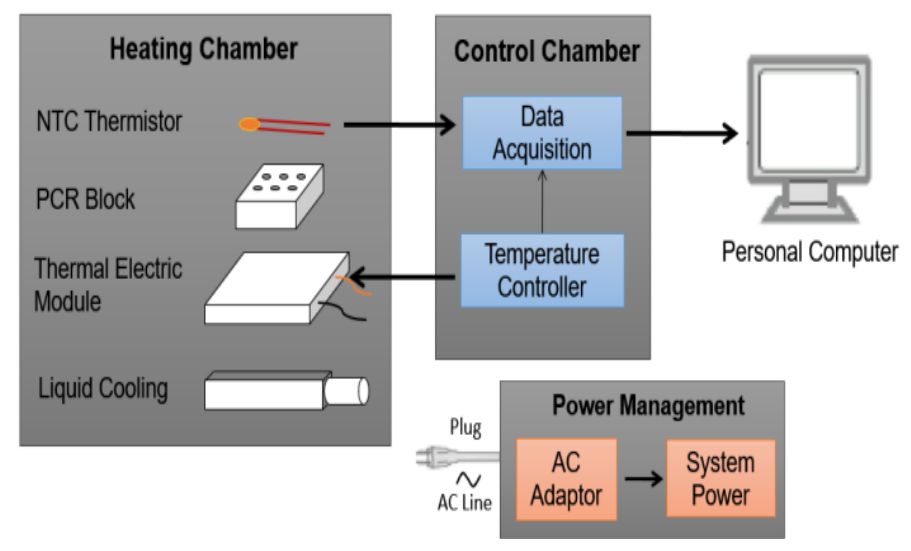

Fig. 1 Block diagram of developed thermal cycler system. The system consisted of four section which are heating chamber, control chamber, power management and personal computer.

\section{PI temperature controller}

Fig. 2 shows the block diagram of the PI temperature controller feedback system. The feedback system of PI temperature controller was compared the Steinhart-hart equation output, $V_{i}(t)$ against the NTC thermistor output, $\mathrm{V}_{\mathrm{t}}(\mathrm{t})$. The PI temperature controller generated an output current, I $(\mathrm{t})$ to thermal electric module (Peltier) based on the voltage difference, e $(\mathrm{t})$. The Peltier converted the I into thermal energy, $\mathrm{Q}_{\mathrm{H}}(\mathrm{t})$ which increased the PCR block temperature. The magnitude of $V_{i}(t)$ and $V_{t}(t)$ depended on the magnitude of temperature input, $\mathrm{T}_{\mathrm{i}}(\mathrm{t})$ and the measured of PCR block temperature, $\mathrm{T}_{\mathrm{o}}(\mathrm{t})$. 


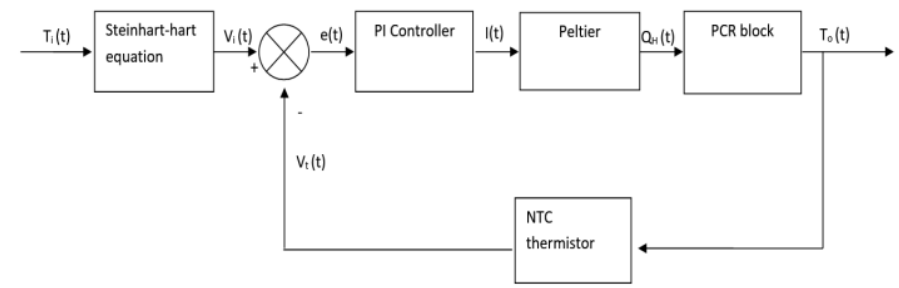

Fig. 2 Block diagram of $\mathrm{PI}$ temperature controller feedback contro system.

In this work, the performance of the PI temperature controller was evaluated at three temperature step inputs. The temperature step inputs were from $50^{\circ} \mathrm{C}$ to $94^{\circ} \mathrm{C}$, from $50^{\circ} \mathrm{C}$ to $72^{\circ} \mathrm{C}$ and from $72^{\circ} \mathrm{C}$ to $94^{\circ} \mathrm{C}$. The temperature rise time and peak temperature overshoot were recorded. The integral gain, $\mathrm{K}_{\mathrm{i}}$ was fixed at $1.8 \mathrm{~A} / \mathrm{Vs}$ and the proportional gain, $\mathrm{K}_{\mathrm{p}}$ of $\mathrm{PI}$ control was changed from 0 to $40 \mathrm{~A} / \mathrm{V}$ with an interval of $5 \mathrm{~A} / \mathrm{V}$ for the PI temperatute controller evaluation.

\section{Graphical User Interface Design}

A customized GUI (Fig. 3) was designed for the developed thermal cycler in the personal computer. It was developed by using National Instruments LabView software. The GUI was made of three sections, PCR block temperature display, data logging and PCR thermal cycling profile setting. A tab control was used as a selector to display each section. The recorded PCR block temperature data was plotted at the PCR block temperature display section in real-time. The temperature data was retrieved from the text file. The file path of the text file was defined in the data logging section. It allowed the GUI to identifiy and determine the location of the saved text file. Fig. 3 shows the PCR thermal cycling profile setting section. The parameters of PCR thermal cycling profile and Steinhart-hart equation constant were insearted in this section. The parameters of the the PCR thermal cycling profile setting Steinhart-hart equation constant were obtained from the Table 1 and TCS651 datasheet, respectively.

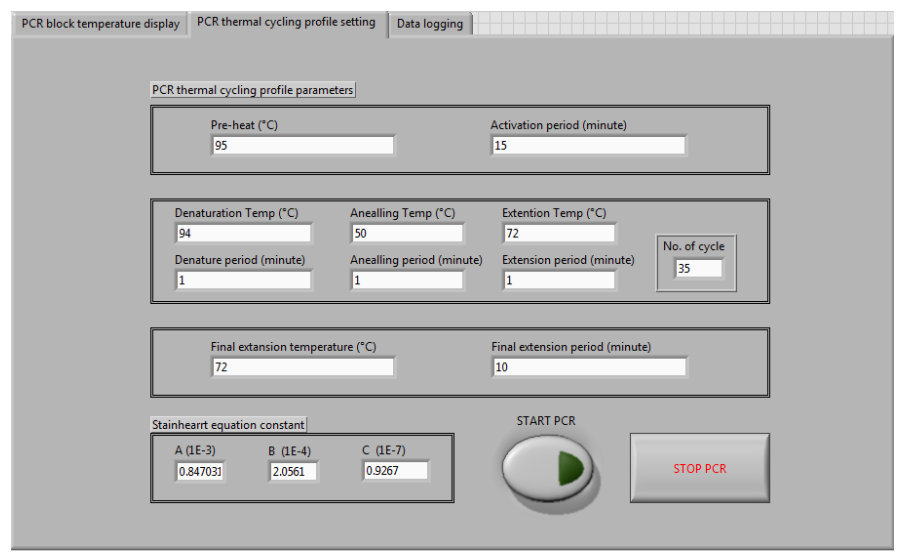

Fig. 3 The PCR thermal cycling profile setting section of the developed GUI. The section allowed user to define the parameters of PCR thermal cycling profile and Steinhart-hart equation constant.

\section{RESULTS AND DISCUSSION}

\section{Developed thermal cycler and graphical user interface}

The portable thermal cycler and customized GUI was successfully developed as shown in Fig. 4. The casing of the thermal cycler was built by Perspex. The DNA heating chamber was designed to be at the top of the developed thermal cycler. Fig. 5 (a) shows the enclosure heating chamber was built by Teflon plastic. Teflon plastic has a high melting temperature $\left(326.8^{\circ} \mathrm{C}\right)$ which is able to hold the PCR block $\left(95^{\circ} \mathrm{C}\right)$ and heating lid $\left(120^{\circ} \mathrm{C}\right)$. Fig. 5 (b) shows the developed PCR block was made with aluminium alloy (6082) material. An aluminium alloy heating lid was developed to prevent the reaction solution to condense on the top of the six microcentrifuge tubes. The condensation in the tubes caused an incomplete DNA amplification and affected the amplification result. The data acquisition device was located at the middle of the developed thermal cycler. The data acquisition device records the PCR block temperature and sends it to the GUI via universal serial bus (USB). The recorded PCR block temperature data was saved in the text file in the personal computer. The liquid cooler and the temperature controller were located at the bottom of developed thermal cycler. The unwanted thermal energy from the PCR block was dissipated through the liquid cooler.

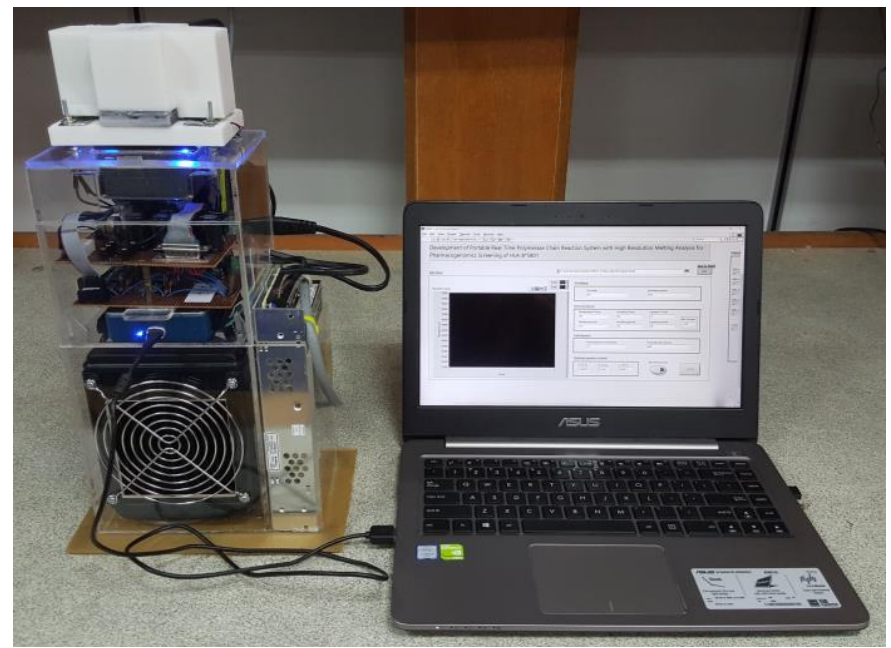

Fig. 4 The developed thermal cycler and graphical user interface in the personal computer. The recorded temperature data was transferred to the personal computer via universal serial bus.

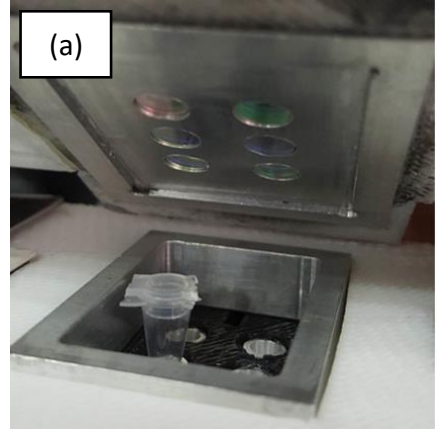

(a)

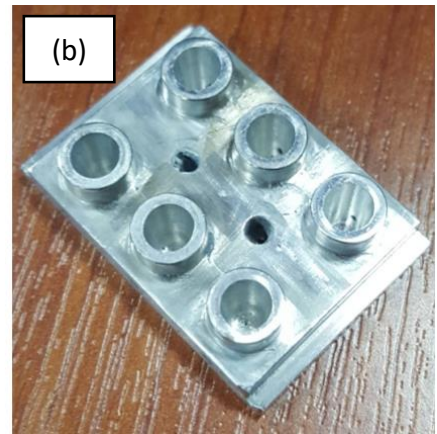

(b)
Fig. 5 The heating chamber of developed thermal cycler. (a) The top and bottom of the heating chamber were the heating lid and PCR block. (b) The six well PCR block built by aluminum alloy, 6082 material.

\section{Proportional-Integral temperature controller tuning}

The temperature ramp rate and temperature overshoot of PI temperature controller was evaluated at three temperature step inputs. The temperature step inputs were $50^{\circ} \mathrm{C}-94^{\circ} \mathrm{C}, 50^{\circ} \mathrm{C}-72^{\circ} \mathrm{C}$ and $72^{\circ} \mathrm{C}-$ $94^{\circ} \mathrm{C}$. The temperature controller was tested under nine different $\mathrm{K}_{\mathrm{p}}$ values and a constant integral gain, $\mathrm{K}_{\mathrm{i}}$ value. The $\mathrm{K}_{\mathrm{i}}$ was fixed at 1.8 $\mathrm{A} / \mathrm{Vs}$.

Table 2 and 3 show the temperature rise times and temperature overshoot under the $\mathrm{K}_{\mathrm{p}}$ value from 0 to $40 \mathrm{~A} / \mathrm{V}$ with an increment of 5 $\mathrm{A} / \mathrm{V}$ for the three temperature step inputs. The temperature rise time is the amount of time the response signal takes to go from $10 \%$ to $90 \%$ of the steady-state value of temperature step input. The temperature overshoot is the amplitude of the process variable (PCR block temperature) where it overshoots the final value of temperature input step. The temperature rise time and temperature overshoot were recorded and analyzed by using MathWorks (MATLAB) software.

Table 2 shows that, as the $K_{p}$ value increases from $0 \mathrm{~A} / \mathrm{V}$ to 10 $\mathrm{A} / \mathrm{V}$, the temperature rise time decreases. The temperature rise times were unchanged for the remaining $\mathrm{K}_{\mathrm{p}}$ value $(15 \mathrm{~A} / \mathrm{V}$ to $40 \mathrm{~A} / \mathrm{V})$. The decrease of the temperature rise time caused the temperature ramp rate to increase. The temperature rise time was unchanged when $K_{p}$ was more than $10 \mathrm{~A} / \mathrm{V}$. This is because the developed thermal cycler 
reached the time constant limit as the $\mathrm{K}_{\mathrm{i}}$ was fixed at $1.8 \mathrm{~A} / \mathrm{Vs}$ in this study.

Table 3 shows that, when the $\mathrm{K}_{\mathrm{p}}$ value increased from $0 \mathrm{~A} / \mathrm{V}$ to 10 $\mathrm{A} / \mathrm{V}$, the peak temperature overshoot value decreased. The peak temperature overshoot value was unchanged as the $K_{p}$ value increased from $15 \mathrm{~A} / \mathrm{V}$ to $40 \mathrm{~A} / \mathrm{V}$. The decrease of peak temperature overshoot was due to the increase of system's damping coefficient as the $\mathrm{K}_{\mathrm{p}}$ value increased.

Table 2 Temperature rise time with proportional gain from 0 to $40 \mathrm{~A} / \mathrm{V}$ for the three temperature step inputs $\left(50^{\circ} \mathrm{C}-94^{\circ} \mathrm{C}, 50^{\circ} \mathrm{C}-72^{\circ} \mathrm{C}\right.$ and $\left.72^{\circ} \mathrm{C}-94^{\circ} \mathrm{C}\right)$

\begin{tabular}{|c|c|c|c|}
\hline $\begin{array}{l}\text { Proportional } \\
\text { gain, } K_{p}(A / V)\end{array}$ & $\begin{array}{l}\text { Time taken } \\
\text { from } 50^{\circ} \mathrm{C} \text { to } \\
94^{\circ} \mathrm{C}(\mathrm{s})\end{array}$ & $\begin{array}{c}\text { Time taken } \\
\text { from } 50^{\circ} \mathrm{C} \text { to } \\
72^{\circ} \mathrm{C}\end{array}$ & $\begin{array}{l}\text { Time taken } \\
\text { from } 72^{\circ} \mathrm{C} \\
\text { to } 94^{\circ} \mathrm{C}(\mathrm{s})\end{array}$ \\
\hline 0 & 8.33 & 3.60 & 4.90 \\
\hline 5 & 8.48 & 3.74 & 4.96 \\
\hline 10 & 7.94 & 3.55 & 4.78 \\
\hline 15 & 7.95 & 3.58 & 4.95 \\
\hline 20 & 7.96 & 3.56 & 4.82 \\
\hline 25 & 7.94 & 3.55 & 4.83 \\
\hline 30 & 7.94 & 3.55 & 4.81 \\
\hline 35 & 7.95 & 3.54 & 4.80 \\
\hline 40 & 7.91 & 3.56 & 4.77 \\
\hline
\end{tabular}

Fig. 6 shows the temperature step response of the developed thermal cycler corresponding to the $\mathrm{K}_{\mathrm{p}}$ values. The figure shows that the decrease $K_{p}$ value resulted in a large temperature overshoot and caused the PCR block temperature to oscillate at the steady state temperature. However, the increase of the $K_{p}$ values caused the time to reach the steady state temperature to increase. Therefore, the maximum temperature ramp rate of the developed thermal cycler in this study, was equal to $5.5^{\circ} \mathrm{C} / \mathrm{s}$ when the temperature step input and $\mathrm{K}_{\mathrm{p}}$ was equal to $50^{\circ} \mathrm{C}$ to $94^{\circ} \mathrm{C}$ and $15 \mathrm{~A} / \mathrm{V}$ respectively.

Table 3 Temperature overshoots with proportional gain from 0 to 40 A $/ \mathrm{V}$ for the three temperature step inputs $\left(50^{\circ} \mathrm{C}-94^{\circ} \mathrm{C}, 50^{\circ} \mathrm{C}-72^{\circ} \mathrm{C}\right.$ and $\left.72^{\circ} \mathrm{C}-94^{\circ} \mathrm{C}\right)$

\begin{tabular}{|c|c|c|c|}
\hline $\begin{array}{l}\text { Proportional } \\
\text { gain, } K_{p}(A / V)\end{array}$ & $\begin{array}{c}\text { Peak } \\
\text { temperature } \\
\text { from } 50^{\circ} \mathrm{C} \text { to } \\
94^{\circ} \mathrm{C}\left({ }^{\circ} \mathrm{C}\right)\end{array}$ & $\begin{array}{c}\text { Peak } \\
\text { temperature } \\
\text { from } 50^{\circ} \mathrm{C} \text { to } \\
72^{\circ} \mathrm{C}\left({ }^{\circ} \mathrm{C}\right)\end{array}$ & $\begin{array}{c}\text { Peak } \\
\text { temperature } \\
\text { from } 72^{\circ} \mathrm{C} \text { to } \\
94^{\circ} \mathrm{C}\left({ }^{\circ} \mathrm{C}\right)\end{array}$ \\
\hline 0 & 112.05 & 80.89 & 111.59 \\
\hline 5 & 105.83 & 75.87 & 107.78 \\
\hline 10 & 98.75 & 74.00 & 100.26 \\
\hline 15 & 94.81 & 73.64 & 95.14 \\
\hline 20 & 94.79 & 73.70 & 94.81 \\
\hline 25 & 94.82 & 73.88 & 94.81 \\
\hline 30 & 94.75 & 74.01 & 94.78 \\
\hline 35 & 94.76 & 73.98 & 94.76 \\
\hline 40 & 94.73 & 74.07 & 94.71 \\
\hline
\end{tabular}

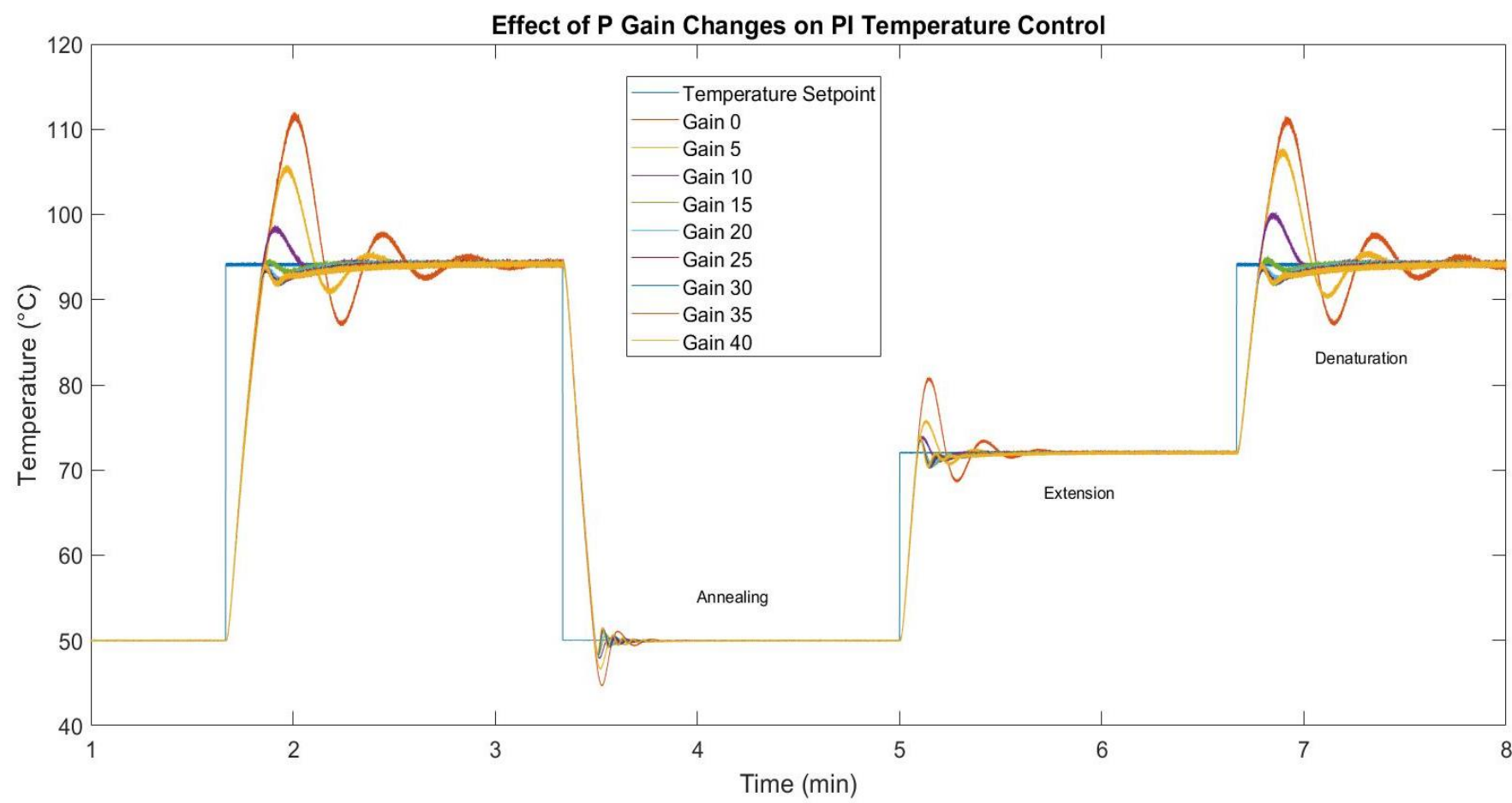

Fig. 6 Comparison of the PCR block temperature step responses to the desired PCR block temperature (Temperature Setpoint). The integral gain of $\mathrm{PI}$ temperature controller was fixed at $1.8 \mathrm{~A} / \mathrm{Vs}$. The results show that as the proportional gain increased, the peak temperature overshoot decreased. The temperature stability of PCR block increased as the proportional gain increased.

\section{Portable thermal cycler system evaluation}

Six microcentrifuge tubes with reaction mixture were inserted into the developed thermal cycler to perform DNA amplification. The DNA amplification result was compared to the Eppendorf Mastercycler nexus. Both thermal cyclers were running under same DNA solution and PCR thermal cycling profile. The $\mathrm{K}_{\mathrm{p}}$ and $\mathrm{K}_{\mathrm{i}}$ of PI temperature controller was configured to $15 \mathrm{~A} / \mathrm{V}$ and $1.8 \mathrm{~A} / \mathrm{Vs}$ respectively. The developed thermal cycler system has lower temperature overshoot and rise time for this configuration setting.
Fig. 7 shows the gel electrophoresis result for six amplified DNA samples using the developed prototype and the Eppendorf Mastercycler nexus. The six amplified DNA samples used were labelled as S1, S2, S3, S4, S5 and S6. The exact same PCR mixtures were prepared as previously mentioned and run on the prototype and the Eppendorf Mastercycler nexus at the same time. Gel electrophoresis was run to analyze the results from both machines as shown in Fig. 7 (a) and (b). A 100 bp DNA ladder was used as a standard reference in the gel electrophoresis results. The 

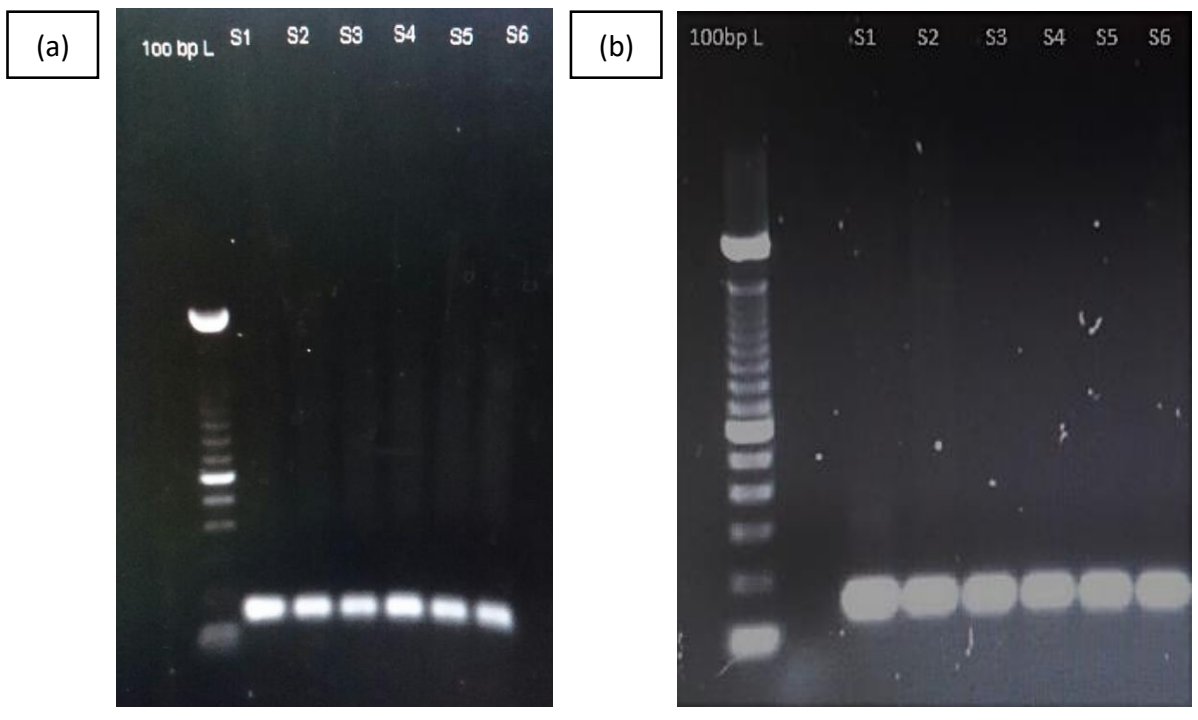

Fig. 7 The gel electrophoresis results shows the six amplified DNA samples (S1, S2, S3, S4, S5 and S6) amplified by the developed prototype in (a) and was compared to results from the Eppendorf Mastercycler nexus gradient machine in (b). Both gels show the 6 samples amplified at the correct target of $150 \mathrm{bp}$.

function of DNA ladder was to determine the size of the PCR product obtained in the gel. The gel electrophoresis result for the prototype in Fig 7 (a) shows that S1 to S6 had single, bright and sharp bands bright at $150 \mathrm{bp}$, indicating the expected specific amplification. This can be compared to Fig 7. (b) where the Eppendorf machine gave similar results, with 6 bands at $150 \mathrm{bp}$. Therefore, the developed thermal cycler has successfully amplified the six DNA samples at the expected molecular weight of $150 \mathrm{bp}$ and has been validated using the Eppendorf Mastercycler nexus gradient machine.

PCR system, Mic qPCR system, MyGo mini real-time PCR system and Chai real-time PCR system). The weight of the developed thermal cycler was lighter compared to the Chai real-time PCR $(-1.4$ $\mathrm{kg}$ ) but heavier compared to the Mini8 Plus $(+1.5 \mathrm{~kg})$, Mic qPCR
$(+1.5 \mathrm{~kg})$ and MyGo mini $(+1.1 \mathrm{~kg})$. The cost of development of the developed

\section{Comparison between developed thermal cycler system and commercial thermal cycler system}

Table 4 shows the developed portable PCR system compared with other four commercial portable PCR systems (Mini8 Plus, real-time thermal cycler was lowest compared to the selling price of the Mini8 Plus (-USD 3489), Mic qPCR (-USD 9835), MyGo mini (-USD 5680) and Chai real-time PCR system (-USD 834). Besides that, the temperature ramp rate of the developed thermal cycler was highest compared to the Mini8 Plus $\left(+2.5^{\circ} \mathrm{C} / \mathrm{s}\right)$, Mic qPCR $\left(+1.5^{\circ} \mathrm{C} / \mathrm{s}\right)$, MyGO mini $\left(+2.5^{\circ} \mathrm{C} / \mathrm{s}\right)$ and Chai real-time PCR $\left(+0.5^{\circ} \mathrm{C} / \mathrm{s}\right)$.

Table 4 Performance comparison between the developed thermal cycler and four commercially available thermal cyclers.

\begin{tabular}{|c|c|c|c|c|c|}
\hline & $\begin{array}{l}\text { Mini8 Plus real- } \\
\text { time PCR system }\end{array}$ & $\begin{array}{l}\text { Mic qPCR } \\
\text { system }\end{array}$ & $\begin{array}{l}\text { MyGo mini real- } \\
\text { time PCR system }\end{array}$ & $\begin{array}{l}\text { Chai real-time } \\
\text { PCR system }\end{array}$ & $\begin{array}{c}\text { Developed } \\
\text { portable thermal } \\
\text { cycler }\end{array}$ \\
\hline $\begin{array}{c}\text { Dimension }(\mathrm{mm}) \\
\mathrm{L} \times \mathbf{W} \times \mathbf{H}\end{array}$ & $205 \times 190 \times 98$ & $150 \times 150 \times 130$ & $120 \times 120 \times 160$ & $280 \times 240 \times 190$ & $220 \times 150 \times 400$ \\
\hline Weight (kg) & 2.1 & 2.1 & 2.5 & 5 & 3.6 \\
\hline Cost (USD) & 6154 & 12500 & 8345 & 3499 & 2665 \\
\hline $\begin{array}{c}\text { Temperature Ramp } \\
\text { rate } \\
\left({ }^{\circ} \mathbf{C} / \mathbf{s}\right)\end{array}$ & 3 & $\begin{array}{l}4 \text { (Heating) } \\
3 \text { (Cooling) }\end{array}$ & $\begin{array}{c}3 \text { (Heating) } \\
1.5 \text { (Cooling) }\end{array}$ & 5 & 5.5 \\
\hline Sample Format & 8 & 45 & 16 & 16 & 8 \\
\hline $\begin{array}{l}\text { Reaction volume } \\
(\mu L)\end{array}$ & 20 & $5-30$ & $10-100$ & $10-15$ & 20 \\
\hline Heating platform & Peltier & Magnetic induction & Peltier & Dual Peltier & Peltier \\
\hline
\end{tabular}

\section{CONCLUSION}

A portable thermal cycler and a customized GUI were successfully designed and built. The GUI was developed for system control and data acquisition. The effect of the proportional gain on the PI temperature controller was studied and evaluated. The results show that the temperature rise and temperature overshoot increased as the proportional gain of the PI temperature controller increased. The increase of the temperature rise time caused the temperature ramp rate of the thermal cycler to decrease. The maximum temperature ramp rate of the developed system was equal to $5.5{ }^{\circ} \mathrm{C} / \mathrm{s}$ when the proportional gain and integral gain of the PI temperature controller were equal to $15 \mathrm{~A} / \mathrm{V}$ and $1.8 \mathrm{~A} / \mathrm{Vs}$ respectively. The developed thermal cycler successfully amplified the six DNA samples and was benchmarked against the Eppendorf Mastercycler Nexus Gradient. While the thermal cycler has been traditionally limited to bulky and 
expensive instruments, we have produced a low-cost, portable thermal cycler built by leveraging modern, consumer grade electronics.

\section{ACKNOWLEDGEMENT}

This research was supported by the Ministry of Higher Education Malaysia (MoHE) under the Fundamental Research Grant Scheme (FRGS/1/2016/TK04/UKM/02/5).

\section{REFERENCES}

R. K. Saiki, S. Scharf, F. Faloona, K. B, Mullis, G. T. Horn, H. A. Erlich and N. Arnheim, 1985. Enzymatic amplification of beta-globin genomic sequences and restriction site analysis for diagnosis of sickle cell anemia. Science 230(4732), 1350-1354.

K. B. Mullis and F. A. Faloona, 1987. Specific synthesis of DNA in vitro via a polymerase-catalyzed chain reaction. Methods in Enzymology 155, 335-350.

G. L. Shipley. 2008. Real-Time PCR: From Theory to Practice. In Reviews in Cell Biology and Molecular Medicine, R. A. Meyers (Ed.), 481-523.

K. B. Mullis. 1990. The unusual origin of the polymerase chain reaction. Scientific American 262(4), 56-61.

T. M. Powledge. 2004. The polymerase chain reaction. Advances in Physiology Education 28(2), 44-50.

K. Mullis, F. Faloona, S. Scharf, R. Saiki, G. Horn and H. Erlich. 1986 Specific enzymatic amplification of DNA in vitro: The polymerase chain reaction. Cold Spring Harbor Symposia on Quantitative Biology 51, 263 273.

D. P. Clark and N. Pazdernik. 2013. In Molecular Biology (Second Edition), Academic Press, Boston.

E. T. Lagally, P. Simpson and R. Mathies. 2000. Monolithic integrated microfludic DNA amplification and capillary electrophoresis analysis system. Sensor and Actuators B 63, 138-146.

Q. H. Wang, Y. Tan and H. Q. Gong. 2003. An integrated system for real-time PCR analysis based on microfluidc biochip. International Journal of Computational Engineering Science 4 (2), 285-288.

D. J. Sadler, R. Changrani, P. Robert, C. F. Chou and F. Zenhausem. 2003. Thermal management of BioMEMS: Temperature control for ceramicbasedPCR and DNA detection devices. IEEE Transactions on Components and Packaging Technologies 26(2), 309-316.

J. Chiou, P. Matsudaira, A, Sonin and D. Ehlich. 2001. A closed-cycle capillary polymerase chain reaction machine. Analytical Chemistry 73(9), 2018-2021.

A. O'Dwyer. 2009. Handbook of PI and PID Controller Tuning Rules $\left(3^{\text {rd }}\right.$ edition). Imperial College Press. Covent Garden.

Y. H. Kim, L. Yang, Y. S. Bae and S. R. Park. 2008. Performance evaluation of thermal cyclers for PCR in a rapid cycling condition. Biotechniques 44(4), 495-496.

S. T. John A. and C. P. Price. 2014. Existing and emerging technologies for point-of-care testing. The Clinical Biochemist Reviews 35(3), 155-167.

Wavelength Electronic Inc.. 2005. Technical Note TN-TC01: Optimizing Thermoelectric Temperature Control System (Rev. C). [Online] Avaliable: http://www.teamwavelength.com/download/applicationtechnotes/tn-tc01.pdf Accessed on: April. 20, 2018. 